\section{Koettua, koeteltua, kerrottua - vai yhdessä elettyä? Kokemuksen määritelmät monitieteisessä keskustelussa}

Toikkanen, Jarkko \& Virtanen, Ira (toim.) (2018). Kokemuksen tutkimus VI. Kokemuksen käsite ja käyttö. Lapland University Press. 254 sivua.

KASVATUSTIETEISSÄ tutkimuskohteena olevia ilmiöitä lähestytään usein yksilöiden kokemuksina tutkimushaastattelujen avulla. Opinnäytteissäkin tämä lienee tyyppiratkaisu. Aina ei kuitenkaan opeteta systemaattisesti kokemuksen teoriaa, vaikka sitä sivutaan muun muassa kehityksen, oppimisen ja merkityksenannon ilmiöitä pohdittaessa. Siksi tartuin tähän teokseen kiinnostuneena: monitieteisessä teoksessa määritellään 'kokemusta' tutkimuskohteena.

Kirjallisuudentutkija Jarkko Toikkasen ja puheviestinnän tutkija Ira Virtasen toimittama teos on vuonna 2016 pidetystä kokemustutkijoiden konferenssista ponnistaneen teossarjan kuudes osa. Mukana on johdantoartikkelin lisäksi 11 artikkelia filosofian, taiteentutkimuksen, käyttäytymisterveys- ja yhteiskuntatieteiden piiristä. Tiedetaustojen moninaisuudesta huolimatta kokoelma on eheä, mikä lienee sen ansiota, että kirjoittajilta on odotettu kokemuskäsitteen huolellista määrittelyä. Kieleltään teos on eksaktia, paikoin hyvinkin tiuhaa, mutta laadukkaat artikkelit selittävät hyvin itseään.

\section{ARKIKÄSITE JA TIETEELLINEN KÄSITE}

'Kokemus' on monella tapaa käytetty arkikäsite. Sen systemaattinen käyttö lähtee hahmottumaan ilmiöparien osana: kokemustieto - tieteellinen tieto, itse koettu - kirjasta opittu, kokeneisuus kokemattomuus. Kirja alkaa kahdella selkiyttävällä ja taustoittavalla filosofisella artikkelilla, Jussi Backmannin käsitehistoriallisella ja Jani Kukkolan kokemuksen metatieteellisellä tarkastelulla. Niiden lukeminen helpottaa irtoamista arkikäsitteestä.

Teoksen useissa teksteissä erotetaan ensinnäkin kokemus välittömänä, tajunnallisena ja kehollisena olotilana. Kokemuksellisuus on ihmisen osa: elämme subjektiivisen kokemuksemme välityksellä; kehollisesti, aistimellisesti ja tajunnallisesti. Välittömällä kokemuksella on materiaalinen pohjansa sekä omassa kehossamme että suhteessamme konkreettiseen maailmaan ja sen kohteisiin. Lisäksi sitä määrittävät tekijät ovat vain osittain tiedostettuja. Välitön kokemus on lellistettynä ja muokattuna kokemus on tavallaan "jo mennyttä", vaikea tavoittaa. Tulkittuna, kie-

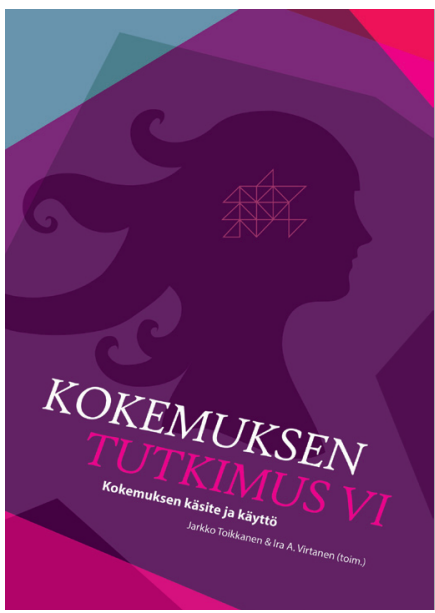

kohteeksi muuttunutta. Tutkimus ei kuitenkaan pysähdy tähän.

\section{KOKEMUS TIETÄMISESSÄ}

JA TUTKIMISESSA

Toinen keskeinen artikkeleissa sivuttu 'kokemuksen' merkitys kuvaa kokemusta tietämisen ja tutkimustyön perustana. Kokemus on tila, jossa luomme suhdetta maailmaan tietämisemme kautta. Kokemusperäinen tutkiminen on todellisuuden koettelua aistinvaraisesti, systemaattisesti ja järkeillen. Kokemusperäinen suhde maailmaan on viime kädessä luonnontieteellisen metodin mutta myös taiteellisen tutkimuksen ytimessä.

Välittömän kokemuksellisuuden sekä rationaalisen tutkimisen väliin aukeaa ymmärtävä, muuntuva tulkkiutumisen prosessi. Se on ymmärtävän tieteenintressin ytimessä ja samalla ihmisten arkinen haaste. Elämme kokemuksessa, mutta kokemus muovautuu sen jatkuvassa ilmaisussa ja prosessoinnissa. Tästä aukeavat subjektiivisen kokemuksen erilaiset rajapinnat ja 
kokemuksellisen tietämisen erilaiset muodot. Ikään kuin törmäämme maailmaan ja omaan rajallisuuteemme, ja samalla muovaamme rajoja uudelleen.

Artikkelit liikkuvat eniten juuri tällä alueella, kokemuksen dynaamisuudessa. Kokemus tapahtuu sen ilmaisussa, pohdinnassa, kokeilemisessa, jakamisessa. Tästä prosessoinnista olen itse eniten oppinut tutustumalla filosofi John Deweyn ajatuksiin. Teoksessa en häntä ihmetyksekseni kuitenkaan kohdannut.

\section{SUBJEKTIIVISEN KOKEMUKSEN YHDYSPINNAT}

Kokemus on merkityssuhteisiin asettumista maailmassa. Se on intentionaalista eli kohteisiin suuntautuvaa, maailmaan kurottuvaa. Vaikka kokemuksen sisältö on subjektiivinen, kokemuksellisuus on jaettua, ja ihmiset voivat kokea yhdessä. Subjektiivisen kokemuksen ajatellaankin olevan kahdella tavalla huokoinen.

Ensinnäkin: yksilö ja maailma sekoittuvat. Yksilö ja ympäristö tai toiset yksilöt - ovat vuorovaikutuksessa ja kokemus rakentuu sosiaalisesti, kuten Teemu Suorsan kasvatuspsykologinen artikkeli kokemuksen kontekstuaalisuutta jäsentää. Asiaa pohditaan kiinnostavasti myös Kai Tuurin ja HannaRiikka Peltolan artikkelissa musiikin jaetusta kuuntelukokemuksesta.

Toiseksi: kokemus on nykyhetkessä, mutta laajenee taaksepäin muistin avulla ja kurottuu eteenpäin kuvittelun avulla. Johanna Nevala ja Ville Pietiläinen näyttävät, miten niin sanottu kuvallinen fenomenologia voi työnohjauksessa toimia keinona kurottua kohti sitä, mitä vielä ei ole. He hakevat irtiottoa paitsi kielen järjestyksistä myös ohjaajan ja ohjattavan välisestä valtasuhteesta. Taide voi kommunikoida tavalla, joka irtoaa kielen kategorioista ja lineaarisuudesta.

\section{KOKEMUKSEN KEHOLLISUUS JA KIELELLISYYS}

Useissa artikkeleissa tarkastellaan kokemuksen kehollista perustaa. Kehomme on materiaalinen ja biologinen asia, joka luo kokemuksemme ehtoja. Miellämme ja tunnemme kehollisesti, kuten opimme hevosvalmennusta käsittelevästä Paula Rossin ja Päivi Lundvallin artikkelista. Buddhalaisen mielenfilosofian kehomielen käsite tulee lähelle näitä tarkasteluja. Joskus "tiedämme" kehollisesti, joskus kielellinen ja kehollinen sulautuvat toisiinsa. Lotta Kähkönen pohtii vaikuttavasti artikkelissaan transihmisten kokemusta kehostaan runouden lävitse. Tarkastelussa kielellisyys ja kehollisuus liukuvat toisiinsa ja rakentavat toisiaan.

Kokemus, kertominen ja tunteet ovat kiinteässä yhteydessä. Kertominen on kokemuksen välittämisen genre. Kokemuskertomukset ovat median käyttövoimaa ja saavat usein autenttisuuden ja tunnevoimaisen samaistuttavuuden todistustehtävän. Kokemuksellisuus on vuorovaikutuksessa käytetty resurssi, kuten Hanna Rautajoki näyttää etnometodologisessa analyysissaan affektisesta kokemuksesta tv-haastattelussa. Myös Virpi Tökkäri erittelee koke- muskertomuksia analysoidessaan hiihtokeskustyöntekijöiden kokemuksista työstään.

\section{KOKEMUS NÄKÖKULMANA, POSITIONA JA ASIANOMISTAJUUTENA}

Kokemuksen kuuleminen voi tarkoittaa myös äänen antamista ryhmälle, jonka ääni on ollut vaiettu tai vähätelty. Niin sanottu kokemusasiantuntijuus - eletty suhde ilmiöön - tuottaa asianomistajuuteen perustuvaa tietoa. Marjaana Jones tarkastelee kokemusta tietämisen muotona terveydenhuollon piirissä. Kokemusasiantuntija tietää sairaudesta jotain ratkaisevasti erilaista kuin terveydenhuollon ammattilainen. Artikkelissa näkyy, että kokemusasiantuntijuus "professionaalistuu". Väheneekö sen omintakeisuus silloin?

Välittömimmin kokemuksesta kommunikoi taide. Taiteellinen tutkimus tutkii maailmaa osallistaen ja kokemuksellisuudessa tutkivasti liikkuen, kuten Taneli Tuovinen ja Riikka Mäkikoskela osoittavat taiteellisen tutkimuksen jäsennyksessään.

Innostuin teoksesta ja aion käyttää sitä tutkimustyössäni. Teoksen luettuani ajattelen, että kokemus ei ole niinkään mielen tai kehon tila kuin tapahtumista. Sen tutkiminen saattaa onnistua parhaiten asettumalla mukaan tapahtumiseen. Kirja on oivallinen kasvatustieteiden metodologian opintoihin, opinnäyteprosesseihin sekä tutkijoiden virikkeeksi.

SANNA VEHVILÄINEN

$K T$, dosentti, työnohjaaja, kouluttaja 